\title{
Bloqueio do Nervo Isquiático Via Médio Lateral da Coxa como Opção Anestésica no Trauma. Relato de Caso *
}

\section{The Lateral Midfemoral approach to Sciatic Nerve Block as an Anesthetic Option to Trauma. Case Report}

Karl Otto Geier ${ }^{1}$

\section{RESUMO}

Geier KO - Bloqueio do Nervo Isquiático Via Médio Lateral da Coxa como Opção Anestésica no Trauma. Relato de Caso

JUSTIFICATIVA E OBJETIVOS: Nos pacientes com trauma de membros inferiores e com estômago cheio, tantos os bloqueios de plexos nervosos como os bloqueios de nervos periféricos isolados são procedimentos incomuns, prevalecendo os bloqueios peridural e subaracnóideo como primeira indicação. Este relato de caso registrou a escolha do bloqueio do nervo isquiático, como melhor indicação para anestesia em paciente de estômago cheio e traumatismo grave de pé.

RELATO DO CASO: Paciente do sexo masculino, 50 anos, estado físico ASA II, obeso moderado (IMC = 29,8), hipertenso, motorista de ônibus por 29 anos, com laminectomia lombar descompressiva $\left(L_{4}-L_{5}\right.$ e $\left.L_{5}-S_{1}\right)$, prévia há 10 anos, em uso de antidepressivos, vítima de acidente de motocicleta, após ter-se alimentado. O teste de Mallampati mostrou-se classe III. Após terem sido excluídas várias alternativas de técnicas para a execução da anestesia, a escolha recaiu no bloqueio isquiático como a melhor opção. A mistura anestésica administrada consistiu de $10 \mathrm{~mL}$ de lidocaína a $2 \%$ e $15 \mathrm{~mL}$ de bupivacaína a $0,5 \%$, ambas com adrenalina a 1:200.000, resultando em mais de 15 horas de analgesia.

CONCLUSÕES: A escolha do bloqueio do nervo isquiático por via médio lateral da coxa, como opção anestésica de trauma no pé, baseou-se em critérios previamente estabelecidos como a preferência de anestesia regional em pacientes com estômago cheio e candidatos a cirurgias de urgência nos membros; a limitação postural dos pacientes para realizar certas técnicas, como as espinhais; o conhecimento anatômico da inervação somática dos membros e o domínio de técnicas regionais alternativas.

Unitermos: CIRURGIA, Ortopédica: membro inferior; TÉCNICAS ANESTÉSICAS, Regional: bloqueio do nervo isquiático

\footnotetext{
* Recebido do (Received from) Hospital Municipal de Pronto Socorro de Porto Alegre, RS

- Apresentado parcialmente no XI Congresso Brasileiro de Trauma Ortopédico, Bento Gonçalves/RS de 19 a 21 de Maio de 2005

1. Anestesiologista do Hospital Municipal de Pronto Socorro de Porto Alegre/RS; Anestesiologista colaborador da Clindor do Hospital São Lucas da PUC/RS; Certificado na Área de Atuação em Dor pela AMB; Membro Efetivo (Life Member) da Sociedade Européia de Anestesia Regional (ESRA); Mestre em Cirurgia pela UFRGS
}

Apresentado (Submitted) em 31 de maio de 2005 Aceito (Accepted) para publicação em 03 de outubro de 2005

Endereço para correspondência (Correspondence to) Dr. Karl Otto Geier

Rua Coronel Camisão, 172

90540-050 Porto Alegre, RS

E-mail:karlotto@terra.com.br

(C) Sociedade Brasileira de Anestesiologia, 2006

\section{SUMMARY}

Geier KO - The lateral Midfemoral approach to Sciatic Nerve Block as an Anesthetic Option to Trauma. Case Report

BACKGROUND AND OBJECTIVES: Both nervous plexus block and isolated peripheral nerve block are uncommon procedures for patients with lower limb trauma or full stomach, prevailing epidural and spinal blocks as the primary indication. This case report describes the choice of sciatic nerve block as the best indication for a patient with full stomach and severe foot trauma.

CASE REPORT: Male patient, 50 years old, physical status ASA II, moderately obese $(B M I=29.8)$, hypertensive, bus driver for 29 years with decompressive lumbar laminectomy $\left(L_{4}-L_{5}\right.$ e $\left.L_{5}-S_{1}\right) 10$ years ago, under antidepressants, who suffered motorcycle accident soon after having eaten. Mallampati test was class III. After excluding several anesthetic techniques, sciatic nerve block was chosen as the best option. Anesthesia was induced with $10 \mathrm{~mL}$ of $2 \%$ lidocaine and $15 \mathrm{~mL}$ of $0.5 \%$ bupivacaine, both with epinephrine 1:200 000, resulting in more than 15 hours of analgesia.

CONCLUSIONS: Lateral midfemoral sciatic nerve block as anesthetic option for foot trauma was based on pre-established criteria, such as the preference for regional anesthesia in patients with full stomach and candidates to urgency limb procedures, postural limitation of patients to perform some techniques, such as spinal procedures, anatomic understanding of somatic limb innervation and the mastering of alternative regional techniques.

Key Words: ANESTHETIC TECHNIQUES, Regional: sciatic nerve block; SURGERY, Orthopedic, lower limb

\section{INTRODUÇÃO}

$\mathrm{N}^{\mathrm{s}}$ s pacientes traumatizados, que necessitam procedimentos cirúrgicos nos membros inferiores, a escolha da técnica anestésica está na dependência de vários fatores como a limitação do posicionamento pela dor, necessário para a execução de algumas técnicas regionais; os potenciais problemas associados ao trauma como estômago cheio, instabilidade hemodinâmica, viabilidade das condições normais de acesso às vias aéreas ${ }^{1}$, comorbidades, interação medicamentosa e cirurgias prévias, exigindo dos anestesiologistas uma definição precisa sobre a técnica mais apropriada a ser realizada. O objetivo desse relato foi apresentar um caso de anestesia regional em paciente traumatizado, com estômago cheio. 


\section{RELATO DO CASO}

Paciente do sexo masculino, 50 anos, estado físico ASA II, obeso moderado (IMC $=29,8)$, hipertenso, motorista de ônibus por 29 anos, submetido a laminectomia lombar $\left(\mathrm{L}_{4}-\mathrm{L}_{5} \mathrm{e}\right.$ $L_{5}-S_{1}$ ), há aproximadamente 10 anos, que havia ingerido alimentos havia pouco tempo e fazia uso de fluoxetina, vítima de acidente de trânsito, com motocicleta. Avaliado na emergência e tratado com opióides, foi transferido ao centro cirúrgico para tratamento do trauma no pé, em caráter de urgência. Ao exame físico, apresentava contusões e escoriações generalizadas na bacia, membros superiores e inferiores. Como o pé e perna esquerdos estavam enfaixados e imobilizados por uma tala alta, a magnitude do trauma foi avaliada inicialmente pelas imagens radiográficas (Figura 1) onde múltiplas fraturas cominutivas expostas de metatarseanos com perda de substância dérmica, muscular e óssea foram constatadas.

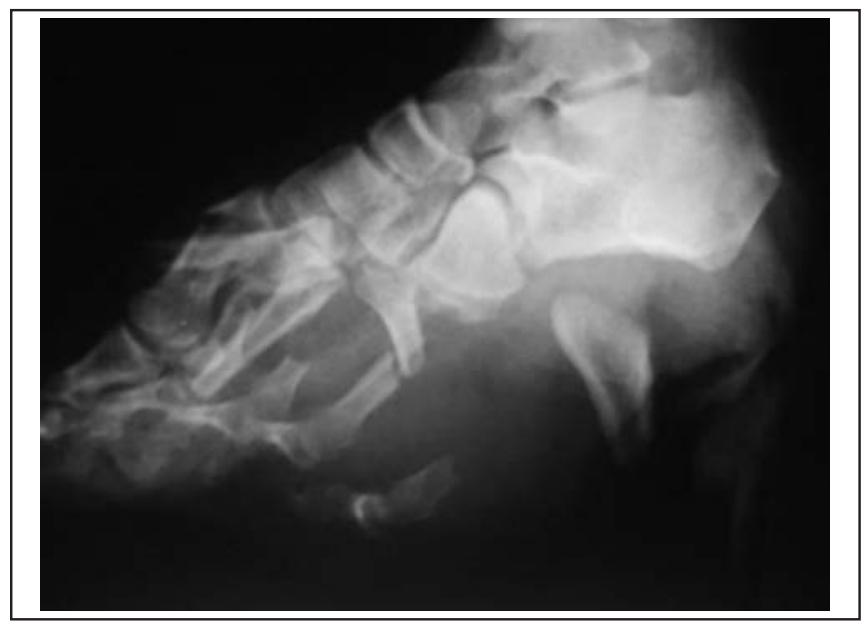

Figura 1 - Avaliação Radiológica do Pé com Trauma Grave

O paciente estava, naquele momento, comunicativo, nauseado, hipertenso $(160 / 100 \mathrm{mmHg})$, corado, teste de Mallampati ${ }^{1,2}$ classe III. A anestesia geral não foi indicada como primeira escolha pela presença de estômago cheio; por outro lado, o posicionamento do paciente, para eventual bloqueio no neuro-eixo, devido à dor, não favorecia anestesia peridural nem subaracnóidea. As opções anestésicas recaíram então no bloqueio do nervo isquiático. Aabordagem anterior foi descartada por causa do IMC elevado cujo exame e identificação dos referenciais anatômicos - crista ilíaca ântero-superior, sínfise púbica e artéria femoral - desencadeavam desconforto e dor na cintura pélvica. A abordagem do nervo isquiático pelos acessos laterais, ao longo da coxa, mostrou-se mais factível. No terço superior lateral, a palpação da tuberosidade isquiática, segundo as técnicas originais ${ }^{3,4}$, previa dificuldades operacionais; no terço inferior lateral, a tala de imobilização que terminava acima do joelho, impedia plena liberdade de acesso àquela região, restando o terço medial lateral da coxa para a execução do bloqueio. Após consentimento verbal e com o paciente imóvel em decúbito dorsal foram identificados o grande trocânter femoral e a borda anterior do músculo bíceps femoral. Após infiltração do tecido celular subcutâneo, com anestésico local, até uma profundidade aproximada de $4 \mathrm{~cm}$, uma agulha $22 \mathrm{G}, 8 \mathrm{~cm}$ para anestesia subaracnóidea, foi introduzida num plano coronal em direção ao nervo isquiático ${ }^{5}$ (Figura 2).

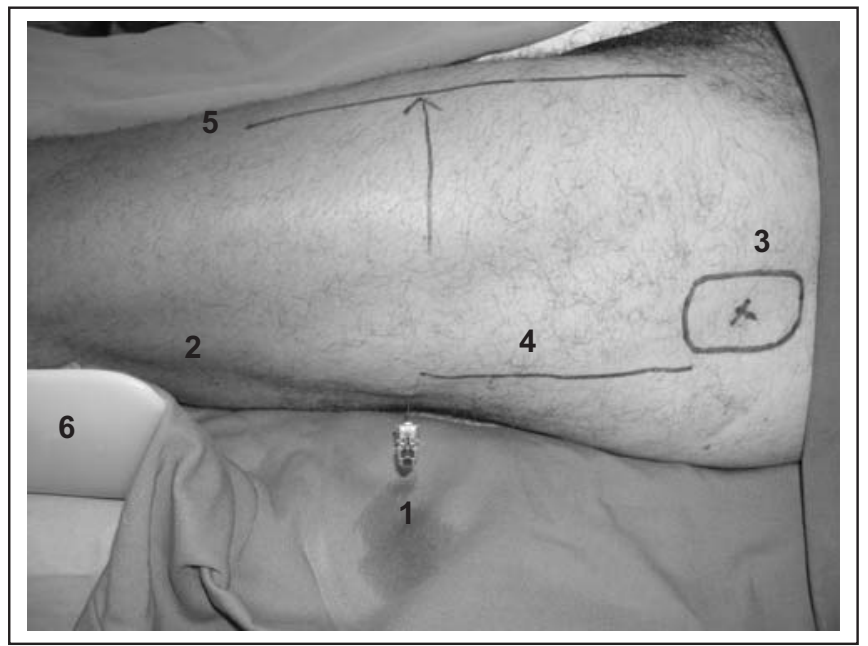

Figura 2 - Momento após o Bloqueio do Nervo Isquiático com AguIha $22 \mathrm{G}$ in situ (1); plano coronal da coxa (2); grande trocânter (3); eixo do fêmur (4); bordo anterior do bíceps (5); tala de imobilização (6)

Disestesias ao longo do nervo isquiático até o pé foram referidas na profundidade de $6 \mathrm{~cm}$. Após aspirações negativas para sangue, injetou-se $25 \mathrm{~mL}$ de uma mistura de anestésicos locais composta por $10 \mathrm{~mL}$ de lidocaína a $2 \%$ e $15 \mathrm{~mL}$ de bupivacaína a 0,5\% ambas com adrenalina a 1:200.000. Sete mililitros da mesma solução foram reservados para eventual necessidade de bloquear o nervo safeno interno (NSI) pela técnica transsartorial ${ }^{6}$. Dez minutos após, o paciente referiu perda de sensibilidade (ausência de dor), e em menos de quinze minutos, o pé esquerdo foi removido da tala, desenfaixado e preparado para a cirurgia. Durante a limpeza inicial das fraturas, o paciente manifestou leve desconforto no pé, ocasião em que se administrou, por via venosa, em doses fracionadas, $4 \mathrm{mg}$ de midazolam e $50 \mu \mathrm{g}$ de fentanil, objetivando a obtenção de sedação consciente. Exaustiva limpeza cirúrgica, desbridamento dos tecidos desvitalizados e fixação dos metatarseanos com fios de Kirchner duraram 55 minutos, restando extensa área cruenta do pé, devido à perda de tecidos (Figura 3).

Manifestando grande satisfação com o procedimento anestésico e analgesia pós-operatória residual, após 14 horas do término do procedimento cirúrgico, o paciente foi transferido para outro hospital para tratamento complementar. 


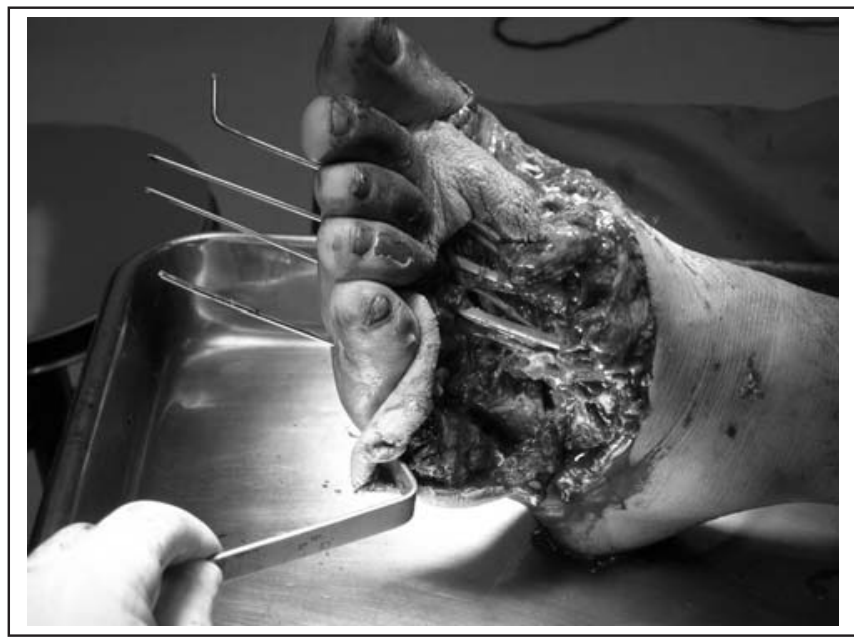

Figura 3 - Fixação Interna dos Metatarseanos com Fios de Kirchner

\section{DISCUSSÃO}

Pacientes politraumatizados ou portadores de traumas ortopédicos que necessitam procedimentos cirúrgicos de urgência são considerados um desafio para o anestesiologista. A maioria apresenta-se em circunstâncias parecidas às do presente caso, e, uma das mais relevantes preocupações éa do estômago cheio, que no trauma associado à dor, pode retardar o esvaziamento gástrico por mais de 24 horas devido à exacerbação da atividade simpática sobre o parassimpático no trato gastrintestinal. Outro problema é com o uso de medicação rotineira pelo paciente. A interação de drogas de uso diário com as da anestesia geral pode resultar em sinergismo farmacológico indesejável. Apesar de o uso de fluoxetina, antidepressivo não tricíclico, não apresentar interação medicamentosa importante com qualquer tipo de agente anestésico, síndrome serotoninérgica ${ }^{7}$ pode surgir com a administração concomitante de opióides no período peri-operatório.

O teste de Mallampati ${ }^{1}$ deve ser rotineiro quando a anestesia geral é programada. Com teste de Mallampati III e estômago cheio, a indução anestésica representava grande risco de aspiração do conteúdo gástrico. Embora devendo idealmente ser realizado na posição sentada, neste paciente o referido teste ocorreu em decúbito dorsal, facilitando a "queda" posterior da língua na faringe, comprometendo a definição das classes I (todo palato e úvula visíveis) a IV (palato mole não visível) de Samsoon e Young ${ }^{2}$.

Os bloqueios de plexo ou de nervos periféricos estão bem indicados nas anestesias de traumas agudos de extremidades por apresentarem vantagens em relação à anestesia espinhal, especialmente por não causarem alterações hemodinâmicas. Entretanto, fato relevante nesses casos, é a dificuldade de mobilização do paciente, devido à dor, para a realização dessas técnicas. Outros aspectos considerados foram a laminectomia prévia e a atividade profissional do paciente, exigindo longos períodos na posição sentada ${ }^{8}$, os quais limitavam a técnica espinhal.
O pé é inervado pelo nervo isquiático, às vezes com pequena participação do NSI, ramo principal do nervo femoral na sua face medial. Recentemente desenvolvida ${ }^{5}$, a anestesia via médio lateral da coxa representa uma atraente alternativa às técnicas proximais e distais do nervo isquiático, cujos trabaIhos atualmente publicados sobre o tema são raros. Esta técnica é mais confiável e previsível, pois nesta região o nervo isquiático não se encontra dividido em seus dois ramos, o nervo fibular comum e nervo tibial. Não obstante isto ocorrer em torno de $15 \%$ dos casos, os dois ramos estão praticamente contíguos, num estreito espaço perineural e, portanto, facilmente anestesiados com apenas uma injeção de solução anestésica. O percurso do nervo isquiático posterior ao fêmur, praticamente no mesmo plano sagital, permitindo monitorizar indiretamente a distância pele-nervo isquiático, e o posicionamento do membro inferior na posição neutra, expondo a sua maior superfície neural à agulha, são outros detalhes anatômicos interessantes desta técnica ${ }^{9}$. Por outro lado, a característica clínica marcante é a instalação quase que simultânea dos bloqueios sensitivo e motor.

Pelo exame radiológico (Figura 1) existia a possibilidade de bloqueio complementar do NSI. Os acessos ao NSI, na altura do cândilo medial da tíbia, com a infiltração subcutânea entre a tuberosidade tibial e o músculo gastrocnêmio ou a abordagem paravenosa (veia safena interna) estavam prejudicados pela tala de imobilização, ao contrário da abordagem transsartorial ${ }^{6}$. Entretanto, isso não foi necessário porque a extensão do trauma no pé não incidiu no território inervado pelo NSI. Quanto ao nervo isquiático, preferiu-se a técnica das parestesias/disestesias em relação ao estimulador de nervo periférico, pois a resposta motora era imprevisível devido à grande destruição tendino-muscular do pé, dificultando a localização final da agulha e o êxito do bloqueio. Por isso, definiu-se a anestesia do nervo isquiático através das parestesias/disestesias pelo contato neural da agulha.

A duração dos bloqueios anestésicos periféricos é em geral mais prolongada do que a dos bloqueios centrais (peridural ou subaracnóideo). Aanalgesia do nervo isquiático costuma ultrapassar 15 horas de duração com bupivacaína a 0,5\% com adrenalina a 1:200.000 na dose de $2 \mathrm{mg} . \mathrm{kg}^{-1}$.

Com 14 horas de pós-operatório, o paciente foi transferido para outro hospital com analgesia pós-operatória residual pelo bloqueio anestésico cirúrgico. Decorridos 40 dias do acidente, o paciente continua em tratamento cirúrgico, com cuidados ortopédicos e de microcirurgia reconstrutiva com satisfatória evolução, embora o prognóstico do pé persista ainda indefinido.

O caso relatado permite concluir que inúmeras variáveis orientaram o anestesiologista na escolha da técnica anestésica mais adequada para o caso. No caso desse paciente politraumatizado, a história clínica e o exame físico; os testes de Mallampati ${ }^{1}$ e de Samsoon Young ${ }^{2}$, entre outros preditores de intubação traqueal difícil; a interação da anestesia geral com as drogas em uso pelo paciente; a priorização da anestesia regional em pacientes com estômago cheio e candidatos a procedimentos cirúrgicos de urgências nos membros; as limitações posturais à realização de bloqueios anestési- 
cos; o conhecimento anatômico da inervação somática dos membros e o domínio de técnicas alternativas em anestesia regional levaram à escolha do bloqueio de nervo isquiático por via médio lateral da coxa, como técnica mais adequada, observando-se bons resultados, tanto para a anestesia, como para a analgesia pós-operatória.

\section{The Lateral Midfemoral approach to Sciatic Nerve Block as an Anesthetic Option to Trauma. Case Report}

\author{
Karl Otto Geier, M.D.
}

\section{INTRODUCTION}

For trauma patients needing lower limb procedures, the anesthetic technique depends on several factors, such as pain-induced impossibility of positioning the patient for some regional techniques; potential problems associated to trauma such as full stomach, hemodynamic instability, difficult conditions to access airways ${ }^{1}$, co-morbidities, drug interaction and previous procedures, requiring from the anesthesiologists a precise definition of the most adequate technique. This case report aimed at describing a case of regional anesthesia in trauma patient with full stomach.

\section{CASE REPORT}

Male patient, 50 years old, physical status ASAII, moderately obese $(\mathrm{BMI}=29.8)$, hypertensive, bus driver for 29 years, submitted to lumbar laminectomy $\left(L_{4}-L_{5}\right.$ e $\left.L_{5}-S_{1}\right)$ approximately 10 years ago, who had just eaten and was under fluoxetine activity, suffered a motorcycle traffic accident. Evaluated in the first aid unit and treated with opioids, patient was referred to the operating center for urgency foot procedure. At physical evaluation, patient presented generalized contusions and bruises on hip, upper and lower limbs. Since left foot and leg were banded and immobilized by a high splint, the magnitude of the trauma was initially evaluated by X-rays (Figure 1) which showed multiple comminuted exposed fractures of metatarsi with loss of skin, muscle and bone.

At that point patient was communicative, nauseated, hypertensive $(160 / 100 \mathrm{mmHg})$, rosy and classified as Mallampati class III ${ }^{1,2}$. General anesthesia was not indicated as first choice due to full stomach; on the other hand, due to pain, patient's positioning for possible neuraxial block did not favor epidural or spinal anesthesia. Anesthetic option was then sciatic nerve block. Anterior approach was discarded due to high BMI where evaluation and identification of anatomic references - anterior-superior iliac crest, pubic symphysis and femoral artery - would trigger discomfort and pelvic waist pain.

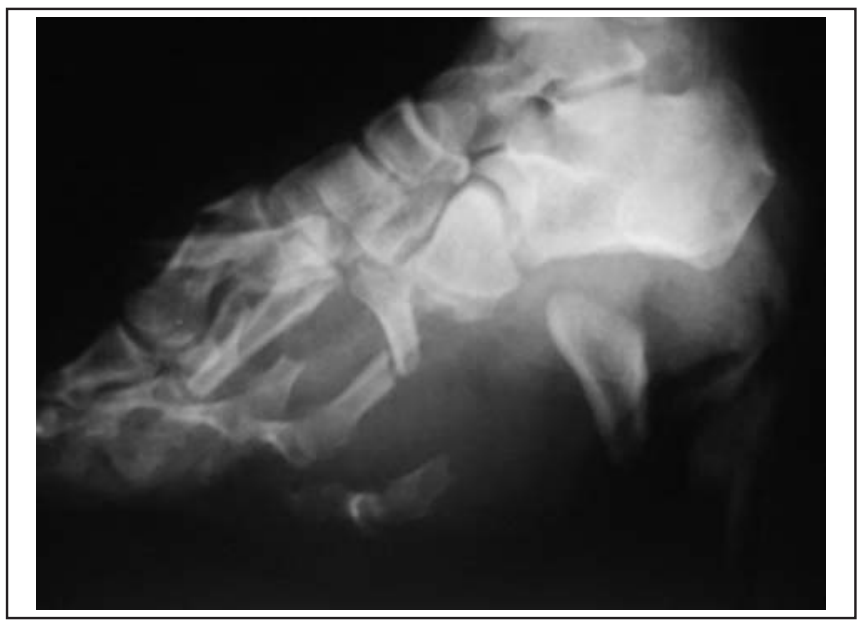

Figure 1 - Radiological Evaluation of Foot with Severe Trauma

Lateral sciatic nerve approach along the thigh was more feasible. In the upper lateral third, sciatic tuberosity palpation according to original techniques ${ }^{3,4}$ indicated operational difficulties; in the lower lateral third, immobilization splint ending above the knee would prevent total access to that region, remaining the mid lateral third for blockade induction. After verbal consent and with the patient immobile and supine, great femoral trocanter and anterior border of the femoral biceps muscle were identified. After subcutaneous infiltration with local anesthetic to a depth of approximately $4 \mathrm{~cm}$, a $22 \mathrm{G}, 8 \mathrm{~cm}$ needle was introduced in the coronal plane toward the sciatic nerve for spinal anesthesia ${ }^{5}$ (Figure 2).

Disesthesias along the sciatic nerve to the foot were referred at $6 \mathrm{~cm}$ depth. After negative blood aspiration, $10 \mathrm{~mL}$ of $2 \%$ lidocaine and $15 \mathrm{~mL}$ of $0.5 \%$ lidocaine, both with epinephrine $1: 200,000$ were injected. Seven milliliters of the same solu-

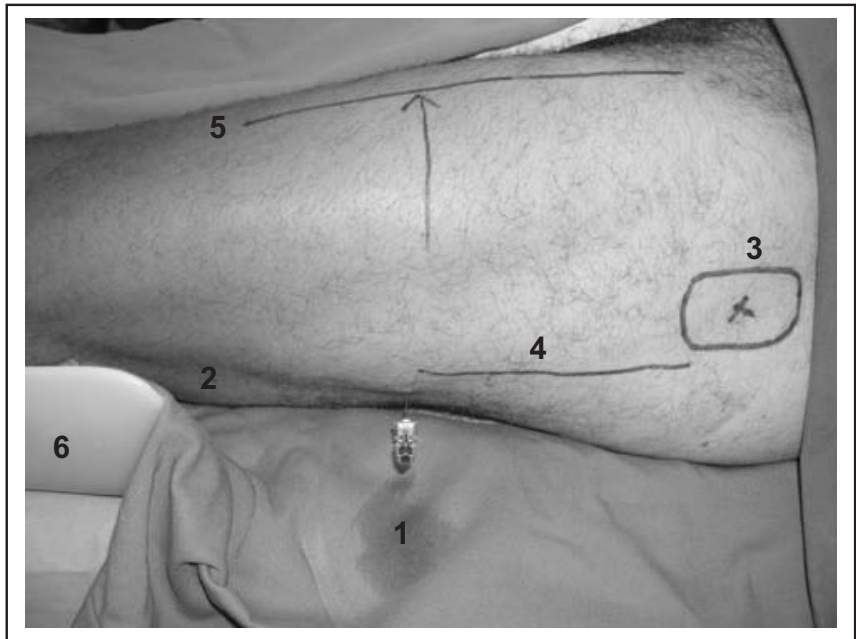

Figure 2 - Moment after Sciatic Nerve Block with 22 G Needle in situ (1); anterior biceps border (2); greater trocanter (3); femoral coronal plane (4); femoral axis (5); immobilization splint above the kenee (6) 
tion were reserved for the possible need to block internal saphenous nerve (ISN) by the transsartorial technique ${ }^{6}$. Ten minutes later the patient referred loss of sensitivity (lack of pain) and in less than 15 minutes the left foot was removed from the splint, unbound and prepared for surgery. During initial fractures cleaning, patient referred mild foot discomfort and received fractional doses of intravenous $4 \mathrm{mg}$ midazolam and $50 \mu \mathrm{g}$ fentanyl to induce conscious sedation. Thorough surgical cleaning, dead tissue debridement and fixation of metatarsi with Kirchner thread took 55 minutes resulting in extensive bloody area due to tissue loss (Figure 3 ).

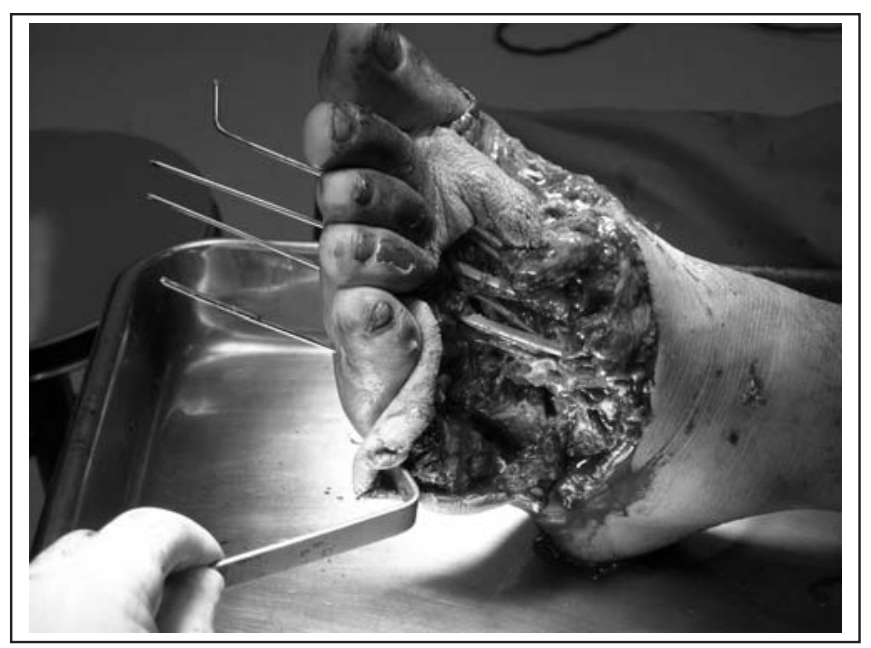

Figure 3 - Internal Fixation of Metatarsi with Kirchner Threads

Very happy with the anesthetic procedure and residual postoperative analgesia, patient was transferred to another hospital for additional treatment 14 hours after surgery completion.

\section{DISCUSSION}

Multiple trauma or orthopedic trauma patients needing urgency procedures are a challenge to the anesthesiologist. Most patients present with conditions similar to our case and a major concern is full stomach which, associated to pain, may delay gastric emptying for more than 24 hours due to the exacerbation of the sympathetic activity on gastrointestinal parasympathetic system. Another problem is routine medication used by the patient.

Routine drugs interaction with general anesthesia may result in undesirable pharmacological synergism. Although fluoxetine, a non-tricyclic antidepressant drug, does not significantly interact with any anesthetic agent, there may be serotoninergic syndrome ${ }^{7}$ with simultaneous perioperative administration of opioids.

Mallampati test ${ }^{1}$ should be routine when general anesthesia is scheduled. With Mallampati III and full stomach, anesthetic induction posed a major risk of gastric content aspiration. Although it should be ideally performed in the sitting position, in our patient it was performed in the supine position to help the posterior "drop" of the tongue in the pharynx, impairing Samsoon Young definitions of classes I (whole palate and uvula visible) to IV (soft palate invisible) ${ }^{2}$.

Plexus or peripheral nerve blocks are adequate indications for acute extremities trauma because they have advantages as compared to spinal anesthesia, especially for not promoting hemodynamic changes. However, a relevant fact in those cases is the difficulty to move the patient due to pain, to perform such techniques. Other considered aspects were previous laminectomy and patient's professional activity, requiring long periods in the sitting position ${ }^{8}$, which would limit the spinal technique.

Foot is innervated by the sciatic nerve, sometimes with minor participation of NSI, major branch of the femural nerve. Recently developed ${ }^{5}$, midfemoral anesthesia is an attractive alternative to proximal and distal sciatic nerve techniques and there are few published papers on the subject. This technique is more reliable and predictable because in this region the sciatic nerve is not divided in its two branches, common fibular and tibial nerves. Notwithstanding this being present in $15 \%$ of cases, both branches are virtually contiguous, in a narrow perineural space, thus easily anesthetized with a single anesthetic injection. Sciatic nerve path posterior to femur, almost in the same sagital plane allowing the indirect monitoring of the skin-sciatic nerve distance and the positioning of the lower limb in the neuter position exposing its largest neural surface to the needle are other interesting anatomic details of this technique ${ }^{9}$. On the other hand, marked clinical characteristic is the almost simultaneous installation of sensory and motor blocks.

According to radiological results (Figure 1), there was the possibility of NSI blockade. Accesses to SNI at the medial condyle of the tibia with subcutaneous infiltration between the tibial tuberosity and the gastrocnemius muscle or the paravenous approach (internal saphenous vein) were impaired by the immobilization splint, as opposed to the transsartorial approach ${ }^{6}$. However this was not needed because foot trauma extension has not reached the territory innervated by the NSI. As for the sciatic nerve, we decided for the paresthesias / disesthesias technique with regard to the peripheral nerve stimulator because motor response was unpredictable due to major foot tendon-muscle destruction making difficult the final location of the needle and the success of the blockade. So, we defined sciatic nerve anesthesia through paresthesias / disesthesias by neural needle contact.

Peripheral anesthetic block duration is in general longer as compared to central blocks (epidural and spinal). Usually, sciatic nerve analgesia lasts more than 15 hours with 2 mg. $\mathrm{kg}^{-1}$ of $0.5 \%$ bupivacaine and epinephrine $1: 200,000$.

This patient was transferred to a different hospital 14 hours after surgery with residual postoperative analgesia induced by surgical anesthetic block. He is still being treated 40 days after the accident, with orthopedic care and reconstructive 
microsurgery with satisfactory evolution although foot prognosis is still undefined.

This case allows us to conclude that several variables have oriented the anesthesiologist in the choice of the most adequate anesthetic technique for a specific clinical situation. In this patient with multiples trauma, the clinical history and physical evaluation with a high presence of predictive factors for difficult intubation (as the presence of Mallampati ${ }^{1}$ and Samsoon Young ${ }^{2}$ tests among other); the interaction of general anesthesia with drugs used by the patient; the prioritization of regional anesthesia for patients with full stomach and candidates to urgency limb procedures; postural limitations to anesthetic blocks; anatomic understanding of somatic innervation of limbs and the mastering of alternative regional anesthetic techniques, have led to the choice of lateral midfemoral sciatic nerve block as the most adequate technique, with satisfactory results both for anesthesia and postoperative analgesia.

\section{REFERÊNCIAS - REFERENCES}

01. Mallampati SR, Gatt SP, Gugino LD et al - A clinical sign to predict difficult tracheal intubation. Br J Anaesth, 1985;34:429-434.

02. Samsoon GLT, Young JRB - Difficult tracheal intubation: a retrospective study. Anaesthesia, 1987;42:487-490.

03. Ichiyanagi K - Sciatic nerve block: lateral approach with the patient supine. Anesthesiology, 1959;20:601-604.

04. Guardini R, Waldron BA, Wallace WA - Sciatic nerve block: a new lateral approach. Acta Anaesthesiol Scand, 1985;29: 515-519.

05. Pham Dang - Midfemoral block: a new lateral approach to the sciatic nerve. Anesth Analg, 1999;88:1426.

06. van der Wal M, Lang AS, Yip RW - Transsartorial approach for saphenous nerve block. Can J Anaesth, 1993;40:542-546.

07. Boyer E, Shannon M - The serotonin syndrome. N Engl J Méd, 2005; 352:11:1112-1120.

08. Geier KO - Fratura de agulha em bloqueio subaracnóideo. Rev Bras Anestesiol, 2005;55:369-370.

09. Floch H, Naux E, Pham Dang C et al - Computed tomography scanning of the sciatic nerve posterior to the femur: practical implications for the lateral midfemoral block. Reg Anesth Pain Med, 2003;28:445-449.

\section{RESUMEN}

Geier KO - Bloqueo del Nervio Isquiático por la Vía Medio Lateral de la Pierna como Opción Anestésica en Traumatismo. Relato de Caso

JUSTIFICATIVA Y OBJETIVOS: En pacientes con traumatismo de los miembros inferiores y que están con estómago lleno, los bloqueos de plexos o de los nervios periféricos son infrecuentes, siendo mas comunes los bloqueos centrales, raquídeo y peridural. Este relato de caso muestra la elección del bloqueo del nervio isquiático como mejor indicación para anestesia en un paciente con estómago Ileno y traumatismo de pie.

RELATO DEL CASO: Paciente masculino, de 50 años, estado físico ASA II, obeso moderado (IMC = 29,8), hipertenso, conductor de ómnibus por 29 años, se le efectuó una laminectomía lumbar hace 10 años, usa anti-depresivos y luego de alimentarse fue víctima de accidente en una motocicleta. El test de Mallanpatti mostró que era de clase III. Luego de excluir varias alternativas de técnicas para la anestesia el bloqueo del nervio isquiático fue elegido como la mejor opción. Se administró una solución con $10 \mathrm{~mL}$ de lidocaína a $2 \%$ y $15 \mathrm{ml}$ de bupivacaína a 0,5\%, ambos con adrenalina a 1:200.000, resultando en más de 15 horas de analgesia.

CONCLUSIONES: La elección de bloqueo del nervio isquiático por la vía medio lateral de la pierna, como opción para la anestesia en traumatismo del pie, se basó en criterios ya establecidos, entre los cuales la preferencia por anestesia regional en pacientes con estómago lleno candidatos a cirugía de urgencia en los miembros, la limitación postural para realizar técnicas por la vía espinal, el conocimiento anatómico de la inervación de los miembros y el dominio de técnicas regionales alternativas. 